The Journal of

Thoracic and Cardiovascular

Surgery

Vol 125, No. 3, March 2003

\title{
The prisoner dilemma: Should convicted felons have the same access to heart transplantation as ordinary citizens? Opposing views
}

Martin F. McKneally, MD, PhD

Robert M. Sade, MD ${ }^{\mathrm{b}}$

From the Department of Surgery and Joint Centre for Bioethics University of Toronto, Toronto General Hospital, University Health Network, Toronto, Ontario, Canada, ${ }^{a}$ and the Institute of Human Values in Health Care, Medical University of South Carolina, Charleston, SC. ${ }^{\mathrm{b}}$

Received for publication March 26, 2002; accepted for publication April 1, 2002.

Address for correspondence: Martin F. McKneally, MD, 77 Forest Grove Dr, Toronto, Ontario Canada M2K 1Z4 (E-mail: martin.mckneally@utoronto.ca); Robert M. Sade, MD, Department of Surgery, 96 Jonathan Lucas St, Suite 409, PO Box 250612, Charleston, SC 29425 (E-mail: sader@musc.edu).

J Thorac Cardiovasc Surg 2003;125:451-3

Copyright $(\odot) 2003$ by The American Association for Thoracic Surgery

$0022-5223 / 2003 \$ 30.00+0$

doi: $10.1067 / \mathrm{mtc} .2003 .61$
Case: In January 2002, a 31-year-old resident of a California prison, twice-convicted for armed robbery, was hospitalized at Stanford University Medical Center for heart failure, constantly attended by two armed guards. He became the first prisoner to receive a heart transplant. Because of the shortage of hearts for transplantation, someone else will die for lack of a heart. The cost of aftercare is estimated to be approximately $\$ 1$ million. A storm of protest blew across the country in response to moral questions about allocating this scarce resource to a felon, rather than a law-abiding citizen, and to fiscal questions about the cost of his care. ${ }^{1}$ Should prisoners receive heart transplants?

Editor Craig Miller asked for an opinion about this intuitively disturbing case. Here are two opposing opinions, with their supporting arguments. A dilemma is a situation in which there are strong arguments for adopting each of two contradictory alternatives. As we will see, persuasive arguments can be advanced on both sides. Let us know what you think about this challenging problem.

\section{Prisoners Deserve a Chance to Have a Change of Heart \\ Martin F. McKneally, MD}

The intuitive responses of aghast, law-abiding citizens can be grouped into three clusters. 1. Prisoners have violated the rules of civil society, so they should be punished rather than awarded society's most precious goods. 2. Providing the highest level of medical care to prisoners may encourage criminality. 3 . The fact that 40 million law-abiding US citizens have no insurance to pay for health care intensifies the injustice of awarding the highest level of care to a felon at public expense.

Intuitions are conclusions that we jump to, unmediated by thoughtful analysis. The first generalization, that prisoners should be ranked lower on the recipient list than law-abiding citizens because they are morally inferior or less socially useful, assumes that we can know the internal moral state of another person and can rank human beings according to their social merit, without tainting these judgments with social bias. Not all prisoners are axe murderers or serial rapists; many come from the most disadvantaged classes of society. A categorical decision to exclude prisoners from medical treatment would deprive Nelson Mandela of treatment for his prisonacquired tuberculosis. In general, transplantation policy makers, such as the United Network for Organ Sharing, ${ }^{2,3}$ ethicists, ${ }^{4}$ and lawyers, ${ }^{5}$ have counseled against using gradations of social worth rather than strict medical criteria to decide the allocation of organs when such tragic choices have to be made between potential recipients.

The second intuition that providing high levels of health care to prisoners will 
increase criminal behavior is not borne out by experience, although the circumstances of America's uninsured, unique in the developed world, could lead some desperate patients to criminal behavior. Violations of the law are punishable by deprivation of certain rights and dignities. Society provides that prisoners, although deprived of their freedom of action, will be given food, shelter, safety, and medical care. Depriving prisoners of these benefits has been judged by the US Supreme Court to be a violation of the US constitutional protection from cruel and unusual punishment. ${ }^{6}$ Deprivation of health care would constitute a second punishment for the same crime already punished by incarceration. Prisoners should receive an appropriate and decent level of health care; the lower and upper boundaries of these benefits should be decided by the community providing the benefits. ${ }^{4}$ Citizens whose theory of criminal justice is based on vengeance will seek to minimize these benefits. Those whose thinking about imprisonment is guided by a theory of rehabilitation will favor more liberal educational and health care benefits for prisoners. ${ }^{7}$ There is significant variation between jurisdictions in terms of the expenditures communities have allowed for the health care of prisoners. In Alabama the state spends $\$ 2.75$ per inmate per day; Texans spend \$5.65; in Massachusetts the state spends \$11.96 per inmate per day. ${ }^{8}$ In Britain, Her Majesty's Prison Service "gives prisoners access to the same quality and range of health care services as the general public receives from the National Health Service."9 The European Prison Rules, based on the United Nations Standard Minimum Roles for the Treatment of Prisoners, state that "the [prison] medical services should be organized in close relation with the health administration of the community or nation." 10 Canadian law requires provision of "essential health care conforming to accepted professional standards." 11

Since the upper boundary of health care provided or available to law-abiding citizens is not a bright line, it is not surprising that the upper boundary for prisoners has not been well defined. Because the care of prisoners is clearly in the public domain, it is reasonable for the public to participate in the delineation of this boundary.

Confusion arises when physicians, caring for patients who are prisoners, open the door to the university tertiary center and prisoners are transported through it, accompanied by guards. Once the prisoner-patient in our story passed through the filters between the prison hospital ward and the civilian hospital, decision makers on the cardiac team were forced to make choices involving circumstances beyond their control. The doctors at the "sharp end" of the health care system cannot balance all of the contextual details and prior decisions made by institutions and governments at the "blunt end,"12 nor can they consider the plight of the 40 million uninsured as they make their decision about a single named, imprisoned patient before them in intractable heart failure. On the basis of their training, they follow the fiduciary obligation to do what is best for the patient they are caring for. ${ }^{13}$ This fundamental guide is the basis for the trust that individual patients and society at large feel toward our profession.

In the absence of a community judgment about the upper boundary of acceptable care for prisoners, I believe that the physicians who chose to implant the heart in their prisonerpatient, based on medical indications of benefit and need, were acting in a highly ethical manner, true to their fundamental values and the values of their profession. The public response to their decision signals the need for discourse leading to definition of the unclarified community standards for allocation of scarce health care resources in California.

I am grateful to Jason D'Cruz for background research and helpful discussion of this paper.

\section{References}

1. Podger PJ. Controversial heart transplant: inmate's operation at $\$ 1$ million cost to taxpayers angers many. San Francisco Chronicle 2002 Feb 3.

2. UNOS Policies \& Bylaws. http://www.unos.org/About/policy _main.htm. Accessed March 3, 2002.

3. UNOS Ethics Committee position statement regarding convicted criminals and transplant evaluation. http:/www.unos.org/Resources/ bioethics_whitepapers_convictrecipient.htm. Accessed March 3, 2002.

4. Loewy EH. Textbook of healthcare ethics. New York: Plenum Press; 1996. p. 155.

5. Annas GJ. The prostitute, the playboy and the poet: rationing schemes for organ transplantation. Am J Public Health. 1985;75:187-9.

6. Estelle v Gamble, US Supreme Court, 1976.

7. Facione PA, Scherer D, Attig T. Values and society: an introduction to ethics and social philosophy. Englewood Cliffs (NJ): Prentice-Hall; 1978. p. 110-3.

8. Lamb-Mechanick D, Nelson J. Prison health care survey: an analysis of factors influencing per capita costs. Federal Bureau of Prisons, 2000.

9. Her Majesty's Prison Service. Health care standards for prisoners in England and Wales. London: Prison Service; 1994.

10. The European Prison Rules. Recommendation Number R(87) 3 of The Committee of Ministers. Council of Europe. 1987.

11. Correction and Conditional Release Act, Section 86

12. Reason J. Human error. Cambridge, United Kingdom: Cambridge University Press; 1990.

13. Pellegrino ED, Thomasma DC. The virtues in medical practice. New York: Oxford University Press; 1993. p. 67.

\section{0: Heart Transplants for Prisoners?}

\section{A: Look at Prison Budgets \\ Robert M. Sade, MD}

First, it should be understood that there is no legal right, that is, no entitlement, to health care in the United States. Some have argued that there is a moral right to health care, ${ }^{1}$ and others have held a contrary position. ${ }^{2}$ The fact is that in this country, no one is legally entitled to a heart transplant.

The answer to the question of whether prisoners should receive heart transplants depends on who is asked the question: physicians, the Organ Procurement and Transplantation Network (OPTN), transplant centers, or prison officials. 
No single answer is universally valid for all concerned parties. Let's look at them, one at a time.

In evaluating transplant candidates, physicians should not discriminate on the basis of social worth. ${ }^{3}$ One observer commented on the California prisoner's transplant: "I am outraged. There are good, honest, hardworking members of society that will possibly die waiting for their transplant because someone who chose to live a life of crime ... will get the heart, liver, lungs, kidney, etc." ${ }^{4}$ Using social value ("honest, hardworking" versus "live a life of crime") as a criterion for medical interventions is dangerous; a sordid and shameful history underlies its use in medicine and medical research in mid-twentieth century Europe and America. ${ }^{5,6}$ Psychosocial factors, on the other hand, may justifiably be used as selection criteria, insofar as they may suggest inadequate social support systems or the likelihood of poor compliance with demanding medication regimens. The worth of a prisoner as a human being, however, is the same as the worth of every other individual. The prison sentence is payment for the crime; the prisoner owes nothing more to society, certainly not his or her life. According to the American Medical Association (AMA), physicians should not use social worth as a criterion for consideration for transplantation. ${ }^{7}$

The OPTN is responsible for developing just policies for allocation of cadaveric organs. Our national OPTN (the United Network for Organ Sharing) has rightfully taken a position even more direct than that of the AMA: "One's status as a prisoner should not preclude them [sic] from consideration for a transplant. ... Screening for all potential recipients should be done at the candidacy stage and once listed, all candidates should be eligible for equitable allocation of organs." 8

For the transplant center, the question takes on a pragmatic dimension: Is there money to pay for the transplant? No one can be guaranteed a heart transplant, and this is true everywhere in the world. There are not enough organs to go around, and neither hospitals nor governments have unlimited financial resources. Even so, in our own transplant center, virtually no patient is denied a transplant for lack of money, which can nearly always be found in a combination of personal funds, health insurance, and public programs such as Medicare and Medicaid. But prisoners have no private or public insurance beyond what the prison system can pay. Can prisons pay for transplants?

The answer to the question of whether prisons can pay for transplants is central to the problem of providing transplants to prisoners: Is there enough money to pay for all the health care that may be desirable or even "needed?" The answer is almost certainly, "no." Most prisons have little difficulty providing routine health care to prisoners. But most prison systems cannot afford the huge bills associated with heart transplantation. In the California case, the bill was estimated at around a million dollars for aftercare alone, at least in part due to the need for armed guards in hospitals and during every trip to a clinic for follow-up care.

It is widely known that American prisons are in deep trouble: they are overpopulated, understaffed, and underfunded. ${ }^{9}$ If prisoners in need were to receive heart transplants, where would the hundreds of thousands of dollars for each one come from? What are the opportunity costs of those procedures, that is, what will prisons have to give up to dedicate substantial sums to transplantation? The primary responsibility of prison officials is to provide room, board, security, and health care for prisoners, at reasonable cost. In addressing the question of whether prisoners should receive heart transplants, the ball finally ends up in the court of the prison system. If there is not sufficient money for heart transplantation, and there is every reason to suppose there is not, then prison officials have solid grounds for saying "no" to heart transplants for prisoners.

\section{References}

1. Buchanan A, Brock DW, Daniels N, Wikler D. From chance to choice: genetics and justice. New York: Cambridge University Press; 2000. p. 380-2.

2. Sade RM. Medical care as a right: a refutation. $N$ Engl J Med. 1971;285:1288-92.

3. Council on Ethical and Judicial Affairs, American Medical Association. Ethical considerations in the allocation of organs and other scarce medical resources among patients. Arch Intern Med. 1995;155:29-40.

4. Podger PJ. Controversial heart transplant: inmate's operation at $\$ 1$ million cost to taxpayers angers many. San Francisco Chronicle 2002 Feb 3.

5. Annas GJ, Grodin MA. The Nazi doctors and the Nuremberg Code: human rights in human experimentation. New York: Oxford University Press; 1992.

6. Jones JH. Bad blood: the Tuskegee syphilis experiment. New York: The Free Press 1981.

7. Council on Ethical and Judicial Affairs. Opinion 2.03: Allocation of limited medical resources. Code of Medical Ethics: Current Opinions (2002-2003). Chicago: American Medical Association.

8. UNOS Ethics Committee position statement regarding convicted criminals and transplant evaluation. http://www.unos.org/Resources/ bioethics_whitepapers_convictrecipient.htm,accessed Feb 26, 2002.

9. Butterfield F. Tight budgets force states to reconsider crime and penalties. New York Times 2002 Jan 21;Sect A:1. 